\title{
Functional impairment of Bladder Cancer Patients Post Radical Cystectomy and Urinary Diversion Procedure: A Correlational Study
}

\author{
Essmat A. Mansour \\ Medical Surgical Nursing department .King Saud University College of Nursing
}

\begin{abstract}
Bladder cancer is a life threatening disease; it is a condition of long-term duration, not curable and having many residual features that impose limitations on individual's functional capabilities. Radical cystectomy is the standard treatment for patients with muscle - invasive bladder cancer, it means the total removal of the bladder, there is no doubt that any urinary diversion post radical cystectomy constructed with an impact on patient's future life and might change the activity of daily functional status. There for This study aimed at study the functional impairment post radical cystectomy operation as an indicator of the prognosis in individual patients. A cross-sectional descriptive correlational design was used for the current study using Karnovesky Performance Index, this tool is employed to assess patient's health status in relation to physical activity performance for 100 bladder cancer patients and post radical cystectomy at one of the eight Cancer Institute affiliated to Ministry of Health, in Egypt.The results of this study revealed a deterioration of the functional status of the patients $3 \& 6$ months postoperatively and a statistical significance difference was observed between ages, marital status, having children with the functional status of the patients.

Conclusion and recommendations: it is concluded that functional status of the patients post radical cystectomy decreased 3, 6 months post-operative, and patient more than 50 years, married \& the patients having children were both need care taker and hospitalization, the recommendation of this study is to use a larger sample size and different settings in a further research to ensure generalization and viability of the results
\end{abstract}

Keywords: bladder cancer, radical cystectomy, urinary diversion, Karnovesky performance index.

\section{Introduction}

Cancer diagnosis is often perceived as a traumatic event that changes an individual's basis assumption about the self as effective and powerful ${ }^{(1)}$. In spite of the technological advances nowadays, cancer still cause the patient to feel much suffer, terrible pain and dying before their hopes and goals in life achieved. Bladder cancer is a life threatening disease; it is a condition of long -term duration, not curable and having many residual features that impose limitations on individual's functional capabilities ${ }^{(1)}$.Bladder cancer in Egypt constitutes 30\% of all cancers cases treated in Egyptian Cancer Institute in Egypt , affecting mainly males due to bilharisiasis (schistosomiasis) that is endemic in the branches of Nile River ${ }^{(2)}$.

Radical cystectomy is the standard treatment for patients with muscle - invasive bladder cancer, it means the total removal of the bladder :In men, it includes removal of the bladder, prostate and seminal vesicles, while in women this surgery include removal of the bladder, urethra ,uterus and the anterior wall of the vagina . In both men and women, the pelvic lymphnodes are dissected for pathological evaluation .Once a cystectomy is performed urine must be diverted to another collecting system, which is called urinary diversion procedure $^{(3)}$.

It is well known that oncological surgery in the pelvis is associated with physical dysfunction and limitations ${ }^{(4)}$, in which physical functions has been viewed as interrelated area of physical performance as muscular strength, range of motion and cardiopulmonary endurance ${ }^{(5)}$.moreover, there is no doubt that any urinary diversion post radical cystectomy constructed with an impact on patient's future life and might change the activity of daily functional status ${ }^{(6)}$. In the context of bladder cancer, morbidity associated with the disease and its treatment can lead to impairment in physiological, psychological or behavioral attributes potentially leading to limitations in ability to perform tasks and participation in social demands ${ }^{(7)}$. In addition, it well known there is a positive relationship between health status and physical activity means that, the better the level of activity the better the health and vice versa ${ }^{(8)}$. Despite there are many previous studies that investigate the quality of life of bladder cancer patient post radical cystectomy ${ }^{(9)}$.there is no researches that studied the effect of this major oncological surgery on the physical function of the patient. So, this study aimed at study the functional impairment of the bladder cancer patients post radical cystectomy operation as an indicator of the prognosis in individual patients. 
Aim of the study

This study aimed at study the functional impairment of bladder cancer patients post radical cystectomy operation as an indicator of the prognosis in individual patients.

Methodology

Research design: a cross-sectional descriptive correlational design was used for the current study

Setting

The study was conducted at one of the eight Cancer Institutes affiliated to Ministry of Health, in Egypt.

\section{Subjects of the study:}

Convenient sample of 100 adult patients who fulfill the following criteria:-

- Age ranging from 40 -65 years.

- Patients diagnosed as bladder cancer and scheduled for total cystectomy and urinary diversion operation.

- Free from any associated chronic condition that can affect the physical activity as cerebrovascular accident (CVA) or bone diseases.

- Conscious, able to communicate \& agree to participate in the study.

Tools of the study:

One tool was used in the current study, it consists of two parts:

Part one: is the patient's profile regarding sociodemographic characteristics as: age, sex, marital status, education, residency and presence of children

Part two:is The Karnovesky performance index ${ }^{(10)}$, this tool is employed to assess patient's health status in relation to physical activity performance. The index consists of ten questions, which are answered on a rating scale of 0-100. The score of 80 and more indicate patients rehabilitated, 70-79 indicate self-care only 40-69 indicate patients requires caretaker and 1-39 indicate that patients require institutionalization or hospitalization. But in this study the first and second categories of the tool (rehabilitated /self-care only) were collected together in one category to facilitate interpretations of the results.

\section{Filed work}

1- Official permission to carry out the study from the responsible authoritative was obtained.

2- Patients included in the study were identified using the selection criteria.

3- Patients consent was obtained to participate in the study after explaining the aim of study and complete disclosure of the study was assured.

4- Karnovesky Performance Index used to collect the basic and general data.

5- Data collection: Data was collected within 12 month's period in the Cancer Institute, from beginning of December 2014 to the end of December 2015. Patient's selection was done in accordance with the predetermined sample selection criteria

6- the tool of the study was administered 3 times individually to patients by the researcher: 1-During the preoperative period to establish an entry baseline data. 2-Three months after surgery. 3-Six months after surgery

\section{Statistical Analysis:}

The collected data was organized, tabulated and statistically analyzed using SPSS software statistically computer package version 18. The number and percent distribution was calculated chi-square was used as a test of significant at $\mathrm{P}<0.05$ for interpretation of result.

\section{Ethical Consideration:}

The pertinent research and ethical committees and all the legal guardians of the patients approved the study protocol. Either verbally or written permission was obtained from every patient before participating in the study. No hazards were present. Participants were assured of confidentiality,. Data were only available to the researchers and participants and all patients were informed that they have the right to withdraw from the study at any time

II. Results of the Study

Table(I): Socio-demographic Characteristics of the studied patients in relation to sex.

\begin{tabular}{|c|c|c|c|c|c|c|}
\hline \multirow{4}{*}{ Variables } & \multicolumn{6}{|c|}{ Sex } \\
\hline & \multicolumn{2}{|c|}{ Males } & \multicolumn{2}{|c|}{ Females } & \multicolumn{2}{|c|}{ Total } \\
\hline & \multicolumn{2}{|c|}{$n=61$} & \multicolumn{2}{|c|}{$n=39$} & \multicolumn{2}{|c|}{$\mathrm{N}=100$} \\
\hline & $\mathbf{n}$ & $\%$ & $\mathbf{n}$ & $\%$ & $\mathbf{n}$ & $\%$ \\
\hline \multicolumn{7}{|c|}{ Age in years: } \\
\hline$-<50$ & 17 & 27.9 & 18 & 46.2 & 35 & 35.0 \\
\hline$->50$ & 44 & 72.1 & 21 & 53.8 & 65 & 65.0 \\
\hline \multicolumn{7}{|l|}{ Residence: } \\
\hline - Urban & 17 & 27.9 & 17 & 43.6 & 34 & 34.0 \\
\hline
\end{tabular}




\begin{tabular}{|c|c|c|c|c|c|c|}
\hline - Rural & 44 & 42.1 & 22 & 56.4 & 66 & 66.0 \\
\hline \multicolumn{7}{|l|}{ Education: } \\
\hline - Illiterate or read and & 41 & 67.2 & 26 & 66.7 & 67 & 67.0 \\
\hline - Primary \& secondary & 15 & 24.6 & 13 & 33.3 & 28 & 28.0 \\
\hline - University & 5 & 8.2 & 0 & 0.0 & 8 & 8.0 \\
\hline \multicolumn{7}{|l|}{ Occupation: } \\
\hline - Professional. & 15 & 24.5 & 5 & 12.8 & 20 & 20 \\
\hline - Skilled worker. & 10 & 16.3 & - & - & 10 & 10 \\
\hline - Unskilled worker. & 10 & 16.3 & - & - & 10 & 10 \\
\hline - Farmer. & 40 & 65.6 & 20 & 51.2 & 60 & 60 \\
\hline \multicolumn{7}{|l|}{ Marital status: } \\
\hline - Single & 8 & 13.1 & 6 & 15.4 & 14 & 14.0 \\
\hline - Married & 36 & 59.0 & 17 & 43.6 & 53 & 53.0 \\
\hline -Divorced & 1 & 1.6 & 2 & 5.1 & 3 & 3.0 \\
\hline -Widow & 16 & 26.2 & 14 & 35.9 & 30 & 30.0 \\
\hline \multicolumn{7}{|l|}{ Having children: } \\
\hline -Yes & 43 & 70.5 & 24 & 61.5 & 67 & 67.0 \\
\hline - No & 18 & 29.5 & 15 & 38.4 & 33 & 33.0 \\
\hline
\end{tabular}

Table I:Socio-demographic Characteristics of the studied patients in relation to sex. This table illustrates that $61 \%$ of the total sample were male, while $65 \%$ were among the aged group less than or equal 50 years. The majority of the sample $66 \%$ were resident of rural areas, while $34 \%$ of the sample were from urban. In relation to education, $67 \%$ of the patients were illiterate or read and write regarding the occupation, $60 \%$ were farmers, while $53 \%$ were married, and $67.6 \%$ of the total sample have children.

Table (2) Karnovesky Performance Index among studied patients pre-operatively, $3 \& 6$ months postoperatively.

\begin{tabular}{|l|l|l|}
\hline Period of assessment & No & $\%$ \\
\hline Preoperative & 98 & 98 \\
\hline Rehabilitated \& self-care only & 9 & 2 \\
\hline Need for care taker & 2 & 0 \\
\hline Need for hospitalization & 0 & \\
\hline 3 Months postoperative & & 66 \\
\hline Rehabilitated \& self-care only & 66 & 34 \\
\hline Need for care taker & 34 & 0 \\
\hline Need for hospitalization & 0 & \\
\hline 6 Months postoperative & & 42 \\
\hline Rehabilitated \& self-care only & 42 & 45 \\
\hline Need for care taker & 45 & 13 \\
\hline Need for hospitalization & 13 & \\
\hline
\end{tabular}

Table 2 : Karnovesky Performance Index among studied patients pre-operatively, $3 \& 6$ months postoperatively, it can be easily noticed that the level of performance of those patients deteriorated across the time through the data presented in the above table which indicate that majority of the patients $(98 \%)$ were rehabilitated and self-care only preoperatively, which this percentage decreased by the time to be $(66 \%, 42 \%) 3$ and 6 months postoperatively respectively, while the percentage of the patients that need hospitalization increased from $0 \%$ in both preoperatively and 3 months post-operative to be $13 \% 6$ months postoperatively

Table (3): Karnovesky Performance Index among studied patients pre-operatively in relation to the patient's variables.

\begin{tabular}{|c|c|c|c|c|c|c|c|c|}
\hline \multirow[t]{4}{*}{ Patient's variables } & \multicolumn{8}{|c|}{ Karnovesky Performance Index } \\
\hline & \multicolumn{8}{|c|}{ Preoperative } \\
\hline & \multicolumn{2}{|c|}{$\begin{array}{l}\text { Rehabilitated } \\
\text { \&self-care only }\end{array}$} & \multicolumn{2}{|c|}{$\begin{array}{l}\text { Need for care } \\
\text { taker }\end{array}$} & \multicolumn{2}{|c|}{$\begin{array}{ll}\begin{array}{l}\text { Need } \\
\text { hospitalization }\end{array} & \text { for } \\
\end{array}$} & \multirow[t]{2}{*}{$\mathbf{X}^{2}$} & \multirow[t]{2}{*}{$\mathbf{P}$} \\
\hline & No & $\%$ & No & $\%$ & No & $\%$ & & \\
\hline $\begin{array}{ll}1- & \text { Age: } \\
& <50\end{array}$ & 35 & 100 & 0 & 0 & 0 & 0 & 5.099 & $0.024 *$ \\
\hline
\end{tabular}




\begin{tabular}{|c|c|c|c|c|c|c|c|c|c|}
\hline - & $\geq 50$ & 63 & 96.5 & 2 & 3.1 & $\mathbf{0}$ & $\mathbf{0}$ & & \\
\hline $\begin{array}{l}\text { 2- } \\
\cdot \\
- \\
\end{array}$ & $\begin{array}{l}\text { Sex: } \\
\text { Male } \\
\text { Female }\end{array}$ & $\begin{array}{l}60 \\
38 \\
\end{array}$ & $\begin{array}{l}98.4 \\
97.5\end{array}$ & $\begin{array}{l}1 \\
1\end{array}$ & $\begin{array}{l}1.6 \\
2.5\end{array}$ & $\begin{array}{l}\text { 0 } \\
\text { 0 }\end{array}$ & $\begin{array}{l}\mathbf{0} \\
\mathbf{0}\end{array}$ & 0.030 & 0.863 \\
\hline $\begin{array}{l}\text { 3- } \\
- \\
- \\
\end{array}$ & $\begin{array}{l}\text { Residence: } \\
\text { Rural } \\
\text { Urban }\end{array}$ & $\begin{array}{l}65 \\
33 \\
\end{array}$ & $\begin{array}{r}98.5 \\
97.1 \\
\end{array}$ & $\begin{array}{l}1 \\
1\end{array}$ & $\begin{array}{l}1.5 \\
2.9 \\
\end{array}$ & $\begin{array}{l}\text { 0 } \\
\text { 0 }\end{array}$ & $\begin{array}{l}\mathbf{0} \\
\mathbf{0}\end{array}$ & 2.440 & 0.118 \\
\hline $\begin{array}{ll}4- & 1 \\
- & 1 \\
\text { read\&writ } \\
-\end{array}$ & $\begin{array}{l}\text { Education : } \\
\text { Illiterate or } \\
\text { te } \\
\text { Literate }\end{array}$ & $\begin{array}{l}65 \\
33 \\
\end{array}$ & $\begin{array}{l}97 \\
97.1 \\
\end{array}$ & 0 & $\begin{array}{l}3 \\
0\end{array}$ & 0 & 0 & 0.211 & 0.647 \\
\hline $\begin{array}{ll}\text { 5- } & 1 \\
\text { status: } \\
\text { - } \\
-\end{array}$ & $\begin{array}{l}\text { Marital } \\
\text { Married } \\
\text { Unmarried } \\
\end{array}$ & $\begin{array}{l}45 \\
53\end{array}$ & $\begin{array}{l}95.7 \\
100\end{array}$ & $\begin{array}{l}2 \\
0\end{array}$ & $\begin{array}{l}2.5 \\
0\end{array}$ & $\begin{array}{l}\text { 0 } \\
\text { 0 }\end{array}$ & $\begin{array}{l}\mathbf{0} \\
\mathbf{0}\end{array}$ & 38.787 & 0.001* \\
\hline $\begin{array}{l}\text { 6- } \\
\text { children : } \\
\text { - } \\
\end{array}$ & $\begin{array}{l}\text { Having } \\
\text { Yes } \\
\text { No }\end{array}$ & $\begin{array}{l}65 \\
33\end{array}$ & $\begin{array}{l}97 \\
100\end{array}$ & $\begin{array}{l}2 \\
0\end{array}$ & $\begin{array}{l}3 \\
\text { 0 }\end{array}$ & $\begin{array}{l}\text { 0 } \\
\text { 0 }\end{array}$ & $\begin{array}{l}\mathbf{0} \\
\mathbf{0}\end{array}$ & 0.914 & 0.339 \\
\hline
\end{tabular}

Table 3: Karnoversky Performance Index among studied patients preoperatively. In the preoperative period, this table shows that there was a statistical significant differences between functional status, age and marital status $\mathrm{P}=0.024$ and 0.001 respectively. Unmarried patients and patients who aged less than 50 years were rehabilitated and self-cared.

Table (4): Karnovesky Performance Index among studied patients 3 months postoperative in relation to the patient's variables.

\begin{tabular}{|c|c|c|c|c|c|c|c|c|c|}
\hline \multirow{4}{*}{\multicolumn{2}{|c|}{ Patient's variables }} & \multicolumn{8}{|c|}{ Karnovesky Performance Index } \\
\hline & & \multicolumn{8}{|c|}{ Preoperative } \\
\hline & & \multicolumn{2}{|c|}{$\begin{array}{l}\text { Rehabilitated } \\
\text { \&self-care only }\end{array}$} & \multicolumn{2}{|c|}{$\begin{array}{l}\text { Need for care } \\
\text { taker }\end{array}$} & \multicolumn{2}{|c|}{ Need for hospitalization } & \multirow[t]{2}{*}{$\mathbf{X}^{2}$} & \multirow[t]{2}{*}{$\mathbf{P}$} \\
\hline & & No & $\%$ & No & $\%$ & No & $\%$ & & \\
\hline & $\begin{array}{l}\text { Age: } \\
<50 \\
\geq \mathbf{5 0}\end{array}$ & $\begin{array}{l}19 \\
47\end{array}$ & $\begin{array}{l}54.3 \\
72.3\end{array}$ & $\begin{array}{l}16 \\
18\end{array}$ & $\begin{array}{l}45.7 \\
27.7\end{array}$ & $\begin{array}{l}\mathbf{0} \\
\mathbf{0}\end{array}$ & $\begin{array}{l}\mathbf{0} \\
\mathbf{0}\end{array}$ & 3.239 & 0.070 \\
\hline $\begin{array}{l}\text { 2- } \\
\text { - } \\
\text { - }\end{array}$ & $\begin{array}{l}\text { Sex: } \\
\text { Male } \\
\text { Female }\end{array}$ & $\begin{array}{l}42 \\
24\end{array}$ & $\begin{array}{l}68.8 \\
61.5\end{array}$ & $\begin{array}{l}19 \\
15\end{array}$ & $\begin{array}{l}31.3 \\
38.5\end{array}$ & $\begin{array}{l}\mathbf{0} \\
\mathbf{0}\end{array}$ & $\begin{array}{l}\mathbf{0} \\
\mathbf{0}\end{array}$ & 0.567 & 0.451 \\
\hline $\begin{array}{l}\text { 3- } \\
\text { - } \\
\end{array}$ & $\begin{array}{l}\text { Residence: } \\
\text { Rural } \\
\text { Urban }\end{array}$ & $\begin{array}{l}44 \\
22\end{array}$ & $\begin{array}{l}66.7 \\
64.7 \\
\end{array}$ & $\begin{array}{l}22 \\
12 \\
\end{array}$ & $\begin{array}{l}33.3 \\
38.5 \\
\end{array}$ & $\begin{array}{l}\mathbf{0} \\
\mathbf{0}\end{array}$ & $\begin{array}{l}\mathbf{0} \\
\mathbf{0}\end{array}$ & 0.038 & 0.845 \\
\hline $\begin{array}{l}\text { 4- } \\
\text { \&V } \\
\text { - }\end{array}$ & $\begin{array}{l}\text { Education : } \\
\text { Illiterate or read } \\
\text { Literate }\end{array}$ & $\begin{array}{l}46 \\
14\end{array}$ & $\begin{array}{l}68.7 \\
42.4\end{array}$ & $\begin{array}{l}21 \\
13\end{array}$ & $\begin{array}{l}31.3 \\
39.4\end{array}$ & $\begin{array}{l}0 \\
0\end{array}$ & $\begin{array}{l}0 \\
0\end{array}$ & 0.639 & 0.424 \\
\hline 5- & $\begin{array}{l}\text { Marital Status } \\
\\
\text { Married } \\
\text { Unmarried }\end{array}$ & $\begin{array}{l}27 \\
39\end{array}$ & $\begin{array}{l}57 \\
73.6\end{array}$ & $\begin{array}{l}20 \\
14\end{array}$ & $\begin{array}{l}42.6 \\
26.4\end{array}$ & $\begin{array}{l}\mathbf{0} \\
\mathbf{0}\end{array}$ & $\begin{array}{l}\mathbf{0} \\
\mathbf{0}\end{array}$ & 9.265 & 0.002 \\
\hline $\begin{array}{l}\text { 6- } \\
\text { - } \\
\text { - }\end{array}$ & $\begin{array}{l}\text { Children: } \\
\text { Yes } \\
\text { No }\end{array}$ & $\begin{array}{l}51 \\
15\end{array}$ & $\begin{array}{l}76.1 \\
45.5\end{array}$ & $\begin{array}{l}16 \\
18\end{array}$ & $\begin{array}{l}23.9 \\
54.5\end{array}$ & $\begin{array}{l}\mathbf{0} \\
\mathbf{0}\end{array}$ & $\begin{array}{l}\mathbf{0} \\
\mathbf{0}\end{array}$ & 9.265 & $0.002 *$ \\
\hline
\end{tabular}

Table 4: Shows karnovesky performance Index 3 months postoperative, data presented in this table reveals that there is a statistical significant difference between the functional status and the presence of children $(\mathrm{P}=0.002)$. The patients having children need for caretaker.

Table (5): Karnovesky Performance Index among studied patients 6 months postoperative in relation to the patient's variables.

\begin{tabular}{|c|c|c|c|c|c|c|c|c|c|}
\hline \multirow{4}{*}{\multicolumn{2}{|c|}{ Patient's variables }} & \multicolumn{8}{|c|}{ Karnovesky Performance Index } \\
\hline & & \multicolumn{8}{|c|}{ Preoperative } \\
\hline & & \multicolumn{2}{|c|}{$\begin{array}{l}\text { Rehabilitated } \& \\
\text { self-care only }\end{array}$} & \multicolumn{2}{|c|}{ Need for care taker } & \multicolumn{2}{|c|}{$\begin{array}{ll}\text { Need } & \text { for } \\
\text { hospitalization } & \end{array}$} & \multirow[t]{2}{*}{$\mathbf{X}^{2}$} & \multirow[t]{2}{*}{$\mathbf{P}$} \\
\hline & & No & $\%$ & No & $\%$ & No & $\%$ & & \\
\hline 1- & $\begin{array}{l}\text { Age: } \\
<50 \\
>\mathbf{5 0}\end{array}$ & 16 & 45.7 & 12 & $\begin{array}{r}34.3 \\
50.8\end{array}$ & 7 & 20.0 & 3.239 & 0.070 \\
\hline 2- & Sex: & & & & & & & & \\
\hline
\end{tabular}




\begin{tabular}{|c|c|c|c|c|c|c|c|c|c|}
\hline . & $\begin{array}{l}\text { Male } \\
\text { Female }\end{array}$ & $\begin{array}{l}27 \\
15\end{array}$ & $\begin{array}{l}44.3 \\
38.5\end{array}$ & $\begin{array}{l}30 \\
15\end{array}$ & $\begin{array}{l}49.2 \\
38.5\end{array}$ & $\begin{array}{l}4 \\
9\end{array}$ & $\begin{array}{l}6.6 \\
23.1\end{array}$ & $\mathbf{0 . 3 2 9}$ & 0.567 \\
\hline 3- & $\begin{array}{l}\text { Residence: } \\
\text { Rural } \\
\text { Urban }\end{array}$ & $\begin{array}{l}28 \\
14\end{array}$ & $\begin{array}{l}42.4 \\
41.1\end{array}$ & $\begin{array}{l}32 \\
13\end{array}$ & $\begin{array}{l}48.5 \\
38.2\end{array}$ & $\begin{array}{l}6 \\
7\end{array}$ & $\begin{array}{l}9.1 \\
20.6\end{array}$ & 0.014 & 0.905 \\
\hline $\begin{array}{l}\text { 4- } \\
\text { re }\end{array}$ & $\begin{array}{l}\frac{\text { Education }}{\text { Illiterate or }} \\
\text { ite } \\
\text { Literate }\end{array}$ & $\begin{array}{l}28 \\
14\end{array}$ & $\begin{array}{r}41.8 \\
42.4\end{array}$ & 13 & $\begin{array}{r}47.8 \\
\\
39.4\end{array}$ & 6 & $\begin{array}{r}10.4 \\
18.2\end{array}$ & 0.004 & 0.250 \\
\hline $\begin{array}{l}5- \\
\text { St }\end{array}$ & Marital & $\begin{array}{l}14 \\
28\end{array}$ & $\begin{array}{l}29.8 \\
52\end{array}$ & $\begin{array}{l}22 \\
23\end{array}$ & $\begin{array}{l}46.8 \\
43.4\end{array}$ & $\begin{array}{l}11 \\
0\end{array}$ & $\begin{array}{l}23.4 \\
3.8\end{array}$ & 0.598 & $\begin{array}{l}0.005 \\
*\end{array}$ \\
\hline 6- & $\begin{array}{l}\text { Children: } \\
\text { Yes } \\
\text { No }\end{array}$ & $\begin{array}{l}32 \\
10\end{array}$ & $\begin{array}{l}47.8 \\
30.3\end{array}$ & $\begin{array}{l}30 \\
15\end{array}$ & $\begin{array}{l}44.8 \\
45.5\end{array}$ & $\begin{array}{l}5 \\
8\end{array}$ & $\begin{array}{l}7.5 \\
24.2\end{array}$ & 2.766 & 0.096 \\
\hline
\end{tabular}

Table 5: Illustrates the level of performance according to Karnovesy performance index6 months postoperative the table shows that there is a statistical significant difference between the functionalstatus and the marital status $(\mathrm{P}=0.005)$. Married patients were need for caretaker, while the unmarried group were still rehabilitated and self-cared.

\section{Discussion}

Invasive urinary bladder cancer is an aggressive form with a five-year survival rate reported in $66 \%$ $68 \%$ of male and $58 \%-66 \%$ in female ${ }^{(11)}$. High level of physical activity and performance is considered as a predictor of long survival in those patients ${ }^{(12)}$. Therefore, this study was conducted to study the functional impairment post radical cystectomy and urinary diversion operation as an indicator of the prognosis in individual patients. The findings of this study denoted that the majority of patient were male and over the age of 50 years. This findings is in line with Faysal etal ${ }^{(13)}$, who stated that bladder cancer mainly affect men more than women, Furthermore it is less commonly seen in those younger than 40 years of age and most commonly occurs in people between the ages of 50 to 70 years. Most of the patients in the present study were married and had children, this is because the age of occurrence for bladder cancer is above 40 years, and it is less common to find persons in this age group unmarried. The majority of the included sample were illiterate farmers, this is because the sample is originally from the rural areas.

The results of the current study revealed that, level of performance of those patients deteriorated across the time, majority of the patients were rehabilitated and self-cared only preoperatively, which this Percentage decreased by the time to be near to one third 6 months postoperatively while the percentage of the patients that need hospitalization increased from $0 \%$ in both preoperatively and 3 months post-operative to be $13 \% 6$ months postoperatively, it can be justified by, most of the studied patients were diagnosed late after the cancer became extensive and advanced, also the age of the majority of patients were above 50 with a debilitated patients which logically negatively affect the outcome of the major oncologic surgeries like radical cystectomy and urinary diversion, this comes in line with Meyer etal ${ }^{(14)}$ who stressed that the selection of patient to be candidate to extensive surgeries like radical cystectomy is a crucial aspect not to prevent the occurrence but at least for minimizing the complications and morbidity .Inaddition, the findings of the present study revealed that there was positive significant relation between age and functional status of the studied patients preoperatively, whereas, most of patients aged less than 50 years were rehabilitated and self-cared in comparison to patients aged 50 years and more. This can be clarified by the effect of aging on the outcome of major oncologic surgery, also the older patients may have less ability to resist the stress of the disease and the operation, resulting in higher level of impairment and reduced physical wellbeing. It is noticed that similar result obtained bySharoukh etal ${ }^{(15)}$, who mentioned that, the treatment and management decisions for older patients should be guided by treatments for comorbid conditions, organ function, frailty and cognitive status. Each age cohort brings a wide range of comorbid conditions, depressive affects, physical, social and cognitive limitations, and other indicators of frailty and associated indications of organ decrements and geriatric syndromes.

The study revealed, the unmarried patients were rehabilitated and self-cared in comparison to the married group. It may be because most of the unmarried patients were in age group less than 50 years who can positively react to the disease and its impact,the same clarification can be logically for the result which confirmed that patients having children need for care taker more than patients who have not.In addition, in a similar study Marja etal ${ }^{(16)}$, found that married stroke patients had low scores on the physical functioning when comparing to the unmarried, moreover, In contrast Aizer etal ${ }^{(17)}$, found that unmarried patients are at significantly higher risk of presentation with metastatic cancer, under treatment, and death resulting from their cancer. This study highlights the potentially significant impact that social support can have on cancer treatment, and survival, 


\section{Conclusion}

This study was carried out to study the impairment of physical activity post radical cystectomy among bladder cancer patients and to investigate the effect of selected patient's variables on the level of activity. The study revealed a decreased in the level of activity 3 and 6 months post-operative ,Also the study indicate a strong significant relation between activity level, age and marital status , 3,6 months post-operative .

Based on the results of the current study the following recommendation are emphasized as the following;

- Patient's selection must be considered before the decision of surgery will be taken

- Emphasizing the virtue of continuous periodical check up to help in early detection among general population.

- For the results to be viable, the trial would need to be conducted with a larger sample size.

Limitations of the study;

- The results of the current study can't be generalized because of small sample size.

- Sample was limited to one setting so, it may interfere with the viability of the results.

\section{References}

[1]. Wright $\boldsymbol{L} \&$ Porter $\boldsymbol{P}$. Quality of life assessment in patients with bladder cancer .2007.Nature Clinical Practice Urology 42(4):350355

[2]. Abbas H, Aboziada M, Abdalwanis M, El-Gmal M, Mokhtar A, Abo-ALmagd A, Amr F, \& Elyamany A. Organ preservation in bilarzial bladder cancer in Egypt: single institutional experience.2012 .Journal of Cancer Therapy ,3; 57-63

[3]. Babjuk M, Oosterlinck W, Sylvester R, ,Kaasinen E, Bolle A\& Palou J. EAU guidelines on non-muscle - invasive urothelial carcinoma of the bladder . 2008. Eur Urol ,54;303-14

[4]. Allareddy V, Kenndy J, West M \& Konety B. Quality of life in long-term surviovrs of bladder cancer . 2006.Cancer , 106; 2353-62

[5]. Gambhir P. Functional impaiments post breast cancer surgery: a correlational study.2013. 5(2): 1101-1103

[6]. Geng V, Eelen P, Fillingham S, Holryds S, Kinesbye B, Pearce I \& Vahr S. Good practice in health care . Continent urinary diversion. 2010. European Association of Urologic Nurse.

[7]. Liedberg $\boldsymbol{F}$. Early complications and morbidity of radical cystectomy.2010.25-30.www.europeanurology.com

[8]. Porerud A, Sherif A \&Tollback $\boldsymbol{A}$. The effect of a physical exercise program after radical cystectomy for urinary bladder cancer. A pilot randomized controlled trail. 2014.28 (5):451-459

[9]. Mansour E.Impact of counseling on the QOL of patients with bladder cancer undergoing urinary diversion .PhD Thesis in nursing .Faculty of nursing .Tanta University.ARE.2006.

[10]. Carlson D, Janson W and Kjellst and C.Functional Status of Patients with End Stage Renal Disease, New York, Mosby Co., 1987; $338-44$

[11]. Stull $\boldsymbol{V}$,Snyder $\boldsymbol{C}, \&$ Demark $\boldsymbol{W}$. Lifestyle interventions in cancer survivors: designing programs that meet the needs of this vulnerable and growing population.2007. J Nutr .. 137(suppl) :243S-248S.

[12]. Exercise as it relates to Disease /the effect of physical activity after urinary cancer surgery .http://en.wikibooks.org/wiki/

[13]. Faysal A, \& Wissam $\boldsymbol{K}$. Radical cystectomy is the treatment of choice for invasive bladder cancer .2009. Canadian Urological Association Journal.3(5):409-412

[14]. Meyer J, Blick $\boldsymbol{C}, \&$ Arumainayagam $\boldsymbol{N}$. A three -center experience of orthotropic neobladder reconstruction after radical cystectomy: revisiting the initial experience, and results in 104 ppatients. 2009 .BJU Int:103; 680-3

[15]. Shahrokh F, John P, Micheal J, Pierre I, Sigfried M\& Bemard H. The effect of age and gender on bladder cancer: a critical review of the literature . 2015. BJU.150(3): 300-308

[16]. Marja K, Juha T, Pentti N and Sontanien M.Domains and Determinants of QOL after Stroke Caused by Brain Infraction, 2000; 46-50.

[17]. Aizer A, Ming C, Ellen P, Malika L, Tayler J, Powell L, Tonic K, Karen E, Neil E, Jim C\& Paul L . Marital status and survival in patients with cancer .2013. J Clin Oncol. Doi: 10.1200/JCO.2013.51.580 